\title{
Digestion of milk, fish and soya-bean protein in the preruminant calf: flow of digesta, apparent digestibility at the end of the ileum and amino acid composition of ileal digesta
}

\author{
By P. GUILlOteAU, R. TOULLEC AND J. F. GRONGNET \\ INRA, 65, rue de Saint-Brieuc, 35042 Rennes Cédex, France \\ AND P. PATUREAU-MIRAND AND J. PRUGNAUD \\ INRA, Theix, 63122 Ceyrat, France \\ AND D. SAUVANT \\ INA-PG, 16, rue Claude Bernard, 75005 Paris, France
}

(Received 25 September 1985 - Accepted 27 November 1985)

1. Digesta were collected from eleven preruminant calves fitted with re-entrant (four calves in Expt 1 and three in Expt 2) or single cannulas (four calves in Expt 1) in the terminal ileum. Collection periods lasted $24 \mathrm{~h}$ (Expt 1) or $96 \mathrm{~h}$ (Expt 2).

2. Two milk-substitutes (fish and soya bean) and a control diet were given to the calves. In the control diet, protein was entirely provided by skim-milk powder. In the other two diets, protein was provided mainly by a partially hydrolysed white-fish protein concentrate or a soya-bean protein concentrate prepared by extracting soya-bean meal with hot aqueous ethanol.

3. In Expt 1, flow rates of fresh matter, dry matter, nitrogen and ash exhibited two maxima between 6 and $8 \mathrm{~h}$ after the morning meal and between 4 and $6 \mathrm{~h}$ (control and soya-bean diets) or 6 and $8 \mathrm{~h}$ (fish diet) after the evening meal. Minimum $\mathrm{pH}$ values were observed at times of maximum flow rate. Variations observed in the flow rates and $\mathrm{pH}$ values were larger with fish and especially soya-bean diets than with the control diet.

4. The apparent digestibility of the three diets in the terminal ileum was significantly higher in Expt 2 than in Expt 1: for $\mathrm{N}$, the values were 0.92, 0.83 and 0.75 (Expt 1), and 0.94, 0.87 and 0.88 (Expt 2) with the control, fish and soya-bean diets respectively.

5. The amount of $\mathbf{N}$ apparently absorbed in the terminal ileum represented $90-96 \%$ of the amount that disappeared from the whole digestive tract in Expt 1 and $95-99 \%$ in Expt 2 .

6. In Expt 1 the amino acid (AA) composition of digesta changed little with the flow rate when the calves were given the control diet (from 158 to $179 \mathrm{~g}$ glutamic acid $/ \mathrm{kg} \mathrm{AA}$ ). With the fish and soya-bean diets the AA composition was similar to that observed with the control diet when the flow rate was minimum, but differences became apparent as the flow rate increased $(281$ and $161 \mathrm{~g}$ glutamic acid $/ \mathrm{kg}$ AA for the soya-bean and control diets respectively with maximum flow rate). In Expt 2, the mean compositions of the digesta were very similar to the means obtained in Expt 1.

7. Different comparisons with dietary, endogenous and bacterial proteins indicated that for the three diets a common mixture containing approximately $65 \%$ endogenous and $35 \%$ bacterial proteins reached the terminal ileum. The quantity of dietary protein added to this mixture appeared to be very low with the control diet, but it increased with the flow rate in the case of the fish and soya-bean diets.

8. In Expt 2, the additional undigested protein in the small intestine was richer in glycine with the fish diet and in glutamic acid and aspartic acid with the soya-bean diet compared with the control diet. This undigested fraction probably originated mainly from the fish solubles and the glycinin of soya bean respectively.

9. With the control diet the apparent digestibility of threonine and cystine was always lower than the mean value for all AA while that of methionine was higher $(0.92,0.82$ and 0.96 respectively). Digestibility of all AA was higher for the control diet than corresponding values for the fish and soya-bean diets; these differences were greatest for histidine with the fish diet $(-0.11)$ and for glutamic acid with the soya-bean diet $(-0 \cdot 13)$.

In the preruminant calf, the apparent digestibility of protein substitutes is generally lower than that of milk protein (Toullec et al. 1979 b). To explain these differences, it is of interest to study the effects of protein source on abomasal emptying (Colvin et al. 1969; Toullec et al. 1971; Guilloteau et al. 1975; Smith \& Sissons, 1975; Gaudreau \& Brisson, 
1980), on digestive secretions (Gorrill et al. 1967; Ternouth et al. 1975; Williams et al. 1976; Garnot et al. 1977), on the rate of absorption (Toullec et al. 1979a; Jenkins \& Emmons, 1982), on intestinal morphology and permeability (Smith \& Sissons, 1975; Roy et al. 1977; Barratt \& Porter, 1979; Kilshaw \& Sissons, 1979; Seegraber \& Morrill, 1982) and on the flow of digesta and the digestibility of nitrogen and amino acids (AA) at the end of the ileum. However, there are few results on this latter topic and they mainly concern milk (Mylrea, 1966 a, $b$; Van Hellemond \& Van Weerden, 1973; Assan \& Thivend, 1976; Van Weerden et al. 1977), soya bean (Sissons \& Smith, 1976) and methanol-grown bacteria (Guilloteau \& Toullec, 1980; Guilloteau et al. 1980). Since the microflora of the large intestine produce large modifications, the AA composition of faeces is little affected by the origin of dietary proteins or by the technological treatments to which they are subjected (Patureau-Mirand et al. 1977; Guilloteau et al. 1980). It is most likely that $\mathrm{N}$ absorbed in the large intestine is no longer in the AA form and that it is unfit for use by the calf as shown by Zebrowska et al. (1978) in the pig. To assess the AA digestibility and the origin of apparently non-absorbed protein it is, therefore, advisable to study the AA composition of ileal digesta (Guilloteau et al. 1980).

Two experiments were carried out to study variations in digesta movement, digestibility and AA composition in the distal ileum resulting from replacement of milk casein by fish and soya-bean proteins. These proteins were chosen because of their very different gastric emptying rates and overall digestibilities; fish protein leaves the abomasum much more rapidly (Guilloteau et al. 1975, 1979) but has a higher apparent digestibility than soya-bean protein (Paruelle et al. 1974; Guilloteau et al. 1977). In Expt 1, flow rate, apparent digestibility and AA composition were measured over $24 \mathrm{~h}$. In Expt 2, only the digestibility and AA composition were assessed but the collection periods lasted $96 \mathrm{~h}$; the results of MacRae (1974) and Ehouinsou (1976) suggest that 24-h periods could be too short. Ileal digestibility was compared with values obtained in the whole digestive tract in previous experiments. The AA composition of ileal digesta was compared with that of dietary, endogenous and bacterial proteins in order tentatively to estimate the origin of undigested protein.

\section{EXPERIMENTAL}

Diets

Two milk-substitutes (fish and soya bean) and a control diet were prepared. Protein for the control diet came exclusively from spray-dried skim-milk powder. In the other two diets the major part of the protein $(740 \mathrm{~g} / \mathrm{kg}$ ) was supplied by a fish-protein or a soya-bean-protein concentrate, the remainder being provided by spray-dried whey supplemented with synthetic AA. The compositions of the control and milk-substitute diets used in Expts 1 and 2 are given in Table 1 . There was a 2-year interval between the experiments and dietary compositions differed slightly.

The fish-protein concentrate was processed from white fish by mild enzyme hydrolysis and partial elimination by centrifugation of fat and insoluble protein. The mean composition (g/kg dry matter $(\mathrm{DM}))$ was 850 crude protein $(\mathrm{N} \times 6 \cdot 25), 60$ fat, 60 ash. The soya-bean concentrate was processed from defatted soya-bean meal by extracting sucrose and $\alpha$-galactosides with hot aqueous ethanol. The mean composition $(\mathrm{g} / \mathrm{kg} \mathrm{DM})$ was 650 crude protein, $10 \mathrm{fat}, 50 \mathrm{ash}$. The mean AA compositions of the protein concentrates and of the diets are given in Table 2.

\section{Animals, feeding and collection of digesta}

A total of eleven Friesian male calves were used (eight in Expt 1 and three in Expt 2). Seven of them (four in Expt 1 and three in Expt 2) were each fitted with a re-entrant cannula. 
Table 1. Composition of the control and milk-substitute diets

\begin{tabular}{|c|c|c|c|c|c|c|}
\hline \multirow{2}{*}{$\begin{array}{l}\text { Expt... } \\
\text { Diet... }\end{array}$} & \multicolumn{3}{|c|}{1} & \multicolumn{3}{|c|}{2} \\
\hline & Control & Fish & Soya bean & Control & Fish & Soya bean \\
\hline \multicolumn{7}{|l|}{ Ingredients ( $\mathrm{g} / \mathrm{kg}$ powder) } \\
\hline Source of protein & $681^{*}$ & $208 \uparrow$ & $300 \ddagger$ & $681^{*}$ & $209 \dagger$ & $284 \ddagger$ \\
\hline Tallow§ & 175 & 164 & 171 & 175 & 164 & 171 \\
\hline Whey powder & - & 469 & 450 & - & 469 & 450 \\
\hline Lactose & 92 & 84 & 3 & 92 & 83 & 19 \\
\hline Starch & 30 & 30 & 30 & 30 & 30 & 30 \\
\hline DL-Methionine & $1 \cdot 7$ & $2 \cdot 4$ & 2.5 & $1 \cdot 7$ & $2 \cdot 4$ & $2 \cdot 5$ \\
\hline Lysine hydrochloride & - & $2 \cdot 7$ & $5 \cdot 4$ & - & $2 \cdot 7$ & $5 \cdot 4$ \\
\hline $\mathrm{CaH}_{2}\left(\mathrm{PO}_{4}\right)_{2} \cdot \mathrm{H}_{2} \mathrm{O}$ & $1 \cdot 0$ & $3 \cdot 2$ & $2 \cdot 9$ & $1 \cdot 0$ & $3 \cdot 2$ & $2 \cdot 9$ \\
\hline $\mathrm{MgSO}_{4}$ & 0.34 & 0.45 & $0 \cdot 12$ & 0.34 & 0.45 & $0 \cdot 12$ \\
\hline $\mathrm{NaCl}$ & 0.30 & - & 0.39 & $0 \cdot 30$ & - & 0.39 \\
\hline $\begin{array}{l}\text { Mixture of trace elements, } \\
\text { vitamins and antibiotics }\end{array}$ & 4 & 4 & 4 & 4 & 4 & 4 \\
\hline \multicolumn{7}{|l|}{ Composition ( $\mathrm{g} / \mathrm{kg}$ dry matter) } \\
\hline Protein & 246 & 239 & 259 & 235 & 248 & 253 \\
\hline Fat & 205 & 193 & 190 & 182 & 176 & 183 \\
\hline Ash & 66 & 76 & 79 & 71 & 87 & 83 \\
\hline
\end{tabular}

* Spray-dried skim-milk powder.

$\dagger$ 'CPSP 90', partially-hydrolysed white-fish-protein concentrate; Coopérative de Traitement des Produits de la Pêche, Boulogne-sur-Mer, France.

$\ddagger$ 'Haypro-T', soya-bean-protein concentrate; Hayes Ltd, Ashod, Israel.

$\S$ Tallow homogenized into concentrated skim-milk (control diet) or whey (fish and soya-bean diets) before spray-drying ( $350 \mathrm{~g}$ fat $/ \mathrm{kg}$ dry matter).

$\|$ Providing (mg/kg diet): $\mathrm{CuSO}_{4} .5 \mathrm{H}_{2} \mathrm{O} 25, \mathrm{ZnSO}_{4} . \mathrm{H}_{2} \mathrm{O} 230, \mathrm{MnSO}_{4} . \mathrm{H}_{2} \mathrm{O} 125, \mathrm{KI} 6, \mathrm{CoSO}_{4} .7 \mathrm{H}_{2} \mathrm{O} 2 \cdot 5$, retinol $4 \cdot 13$, cholecalciferol $0 \cdot 15$, DL- $\alpha$-tocopheryl acetate 100 , menadione $2 \cdot 00$, thiamin 6400 , riboflavin $3 \cdot 00$, pyridoxine $7 \cdot 20$, cyanocobalamine $0 \cdot 05$, ascorbic acid 100 , pantothenic acid $2 \cdot 20$, biotin $0 \cdot 75$, nicotinic acid $2 \cdot 20$, pteroylmonoglutamic acid $1 \cdot 00$, choline 780 , betaine 500 , furazolidone 50 , bacitracine 50 .

The proximal part of the cannula was placed $50-150 \mathrm{~mm}$ from the ileo-caecal valve and the distal part either just before the valve (Expt 1) or in the caecum (Expt 2). The ileum was transected and a blind sac was created at each extremity. The other four calves of Expt 1 were each fitted with a simple cannula placed at the end of the ileum. The cannulas (Ash, 1962) were moulded from plastisol (Synthesia, Nogent-sur-Marne, France) with an internal diameter of $11 \mathrm{~mm}$ and a wall thickness of $2.5 \mathrm{~mm}$. The operations were carried out when the animals were 3-5 weeks and 7-8 weeks of age and their live weights were 51-76 kg and 86-102 kg in Expts 1 and 2 respectively. The calves received two meals daily (at 08.00 and 17.00 hours) supplying a total of 48 (Expt 1) or 53 (Expt 2) g DM/kg live weight ${ }^{0.75}$. The diets were prepared to give 125 (Expt 1) or 154 (Expt 2) $\mathrm{g} \mathrm{DM} / \mathrm{kg}$ liquid diet.

In Expt 1, the animals were distributed into four pairs each including one calf fitted with a re-entrant cannula, the other with a simple cannula. The calves of the first three pairs were given successively the control and milk-substitute diets at random during three periods of 5 weeks (transition 1 week, adaptation 1 week, measurements 3 weeks). The animals of the first pair exhibited health disorders at the end of the first experimental period. They were replaced by those of the fourth pair for the following two periods. A $24 \mathrm{~h}$ collection of digesta was made during $1 \mathrm{~d}$ in each of the 3 weeks of measurements of each period. Total digesta from calves fitted with re-entrant cannulas were collected in a vessel surrounded by melting ice and every $2 \mathrm{~h}$ the collected digesta were weighed and homogenized. After $\mathrm{pH}$ measurement, a sample was taken and stored at $-18^{\circ}$. Digesta were not 
Table 2. Amino acid $(A A)$ composition of the protein concentrates and of the control and milk-substitute diets $(\mathrm{g} / \mathrm{kg}$ assayed $\mathrm{AA}$ )

\begin{tabular}{|c|c|c|c|c|c|}
\hline \multirow{2}{*}{ Product*... } & \multicolumn{2}{|c|}{ Concentrate } & \multicolumn{3}{|c|}{ Diet } \\
\hline & Fish & Soya bean & Control & Fish & Soya bean \\
\hline Aspartic acid & $97 \cdot 5$ & $115 \cdot 0$ & $74 \cdot 1$ & 97.2 & $111 \cdot 3$ \\
\hline Threonine & $46 \cdot 0$ & $41 \cdot 5$ & $44 \cdot 8$ & $52 \cdot 1$ & $49 \cdot 0$ \\
\hline Serine & $53 \cdot 2$ & $54 \cdot 9$ & $54 \cdot 5$ & $53 \cdot 4$ & $53 \cdot 7$ \\
\hline Glutamic acid & $143 \cdot 4$ & $184 \cdot 1$ & 199.0 & $149 \cdot 2$ & $179 \cdot 7$ \\
\hline Proline & $59 \cdot 9$ & $55 \cdot 1$ & $92 \cdot 7$ & $61 \cdot 4$ & 57.6 \\
\hline Glycine & $96 \cdot 9$ & $41 \cdot 2$ & $19 \cdot 3$ & $77 \cdot 0$ & 37.9 \\
\hline Alanine & $68 \cdot 4$ & $43 \cdot 7$ & $32 \cdot 6$ & $64 \cdot 0$ & $44 \cdot 8$ \\
\hline Valine & $46 \cdot 2$ & $52 \cdot 0$ & $66 \cdot 4$ & $51 \cdot 0$ & 53.6 \\
\hline Cystine & $10 \cdot 4$ & 15.9 & $8 \cdot 5$ & $13 \cdot 8$ & $17 \cdot 6$ \\
\hline Methionine $\dagger$ & $28 \cdot 3$ & 14.9 & $28 \cdot 7$ & $25 \cdot 8$ & $16 \cdot 3$ \\
\hline Isoleucine & 37.5 & $49 \cdot 0$ & $54 \cdot 0$ & $46 \cdot 2$ & 53.0 \\
\hline Leucine & $69 \cdot 5$ & $76 \cdot 3$ & $92 \cdot 2$ & 77.5 & $82 \cdot 2$ \\
\hline Tyrosine & $32 \cdot 2$ & $40 \cdot 7$ & $49 \cdot 8$ & $31 \cdot 5$ & $38 \cdot 1$ \\
\hline Phenylalanine & 38.9 & 52.6 & 47.6 & 38.9 & $46 \cdot 2$ \\
\hline Lysine† & $79 \cdot 9$ & $64 \cdot 0$ & $74 \cdot 0$ & $82 \cdot 4$ & $71 \cdot 4$ \\
\hline Histidine & $21 \cdot 0$ & $27 \cdot 5$ & $27 \cdot 6$ & $20 \cdot 1$ & $25 \cdot 6$ \\
\hline Arginine & $70 \cdot 9$ & $71 \cdot 6$ & 34.8 & 58.5 & 62.0 \\
\hline $\begin{array}{l}\text { Sum of assayed } A A \\
(g / 16 \mathrm{~g} \text { nitrogen })\end{array}$ & $88 \cdot 4$ & $97 \cdot 4$ & $103 \cdot 1$ & $84 \cdot 8$ & $95 \cdot 7$ \\
\hline $\begin{array}{l}\mathrm{N} \text { of assayed } \mathrm{AA}_{+}^{+} \\
(\% \text { total } \mathrm{N})\end{array}$ & $77 \cdot 7$ & $81 \cdot 8$ & $81 \cdot 7$ & $77 \cdot 4$ & $83 \cdot 0$ \\
\hline
\end{tabular}

* For details of diets and protein concentrates, see p. 572 and Table 1.

† Supplements excluded.

\$ Except amide- $\mathrm{N}$ of asparagine and glutamine.

reintroduced during the collection days since, under our experimental conditions, reintroduction did not seem to have a noticeable effect on flow rate and apparent digestibility measured at the distal ileum of the preruminant calf (Guilloteau \& Toullec, 1980). In calves fitted with a simple cannula a sample intended for AA analysis was deep-frozen as soon as $25 \mathrm{ml}$ digesta had been removed after the beginning of each $2 \mathrm{~h}$ collection period. So, in total, collections were made on nine occasions, each lasting $24 \mathrm{~h}$, for each diet with each type of cannula.

In Expt 2, the calves received successively the control and the milk-substitute diets at random during three experimental periods of 4 weeks (transition 1 week, adaptation 1 week, measurements 2 weeks). During each of these periods, cannulas were disconnected at the end of the week of transition. Total digesta were collected during each of the 2 weeks of measurements from the meal given on Monday morning up to the same hour on Friday morning. They were collected at room temperature in a vessel, containing thymol crystals, which was recharged at each meal. Digesta collected during the day until the evening meal was stored overnight at $4^{\circ}$. The next morning it was admixed with that of the overnight collection, weighed and homogenized; $25 \%$ of the mixed digesta were stored at $-18^{\circ}$ so as to constitute a mean representative sample of $4 \mathrm{~d}$. The last experimental period was extended by 1 week because we omitted to disconnect the cannulas at the end of the week of transition. Digesta were therefore collected during 3 weeks instead of 2 weeks as in the first two periods. In fact results of the 3 weeks were very similar and means were calculated on the basis of seven measurements for each diet. 


\section{Chemical analysis}

Samples of the three diets, fish- and soya-bean-protein concentrates, and freeze-dried ileal digesta collected from re-entrant cannulas were analysed for DM, N, fat and ash according to methods previously described (Guilloteau \& Toullec, 1980).

Samples of the control diet, fish and soya-bean concentrates as well as mean digesta samples were analysed for AA. In Expt 1, three mean digesta samples were prepared for each diet by mixing equal amounts of digesta obtained from calves fitted with a simple cannula when the flow rate observed in calves equipped with a re-entrant cannula was maximum (from 6 to $8 \mathrm{~h}$ and from 12 to $16 \mathrm{~h}$ after the morning meal), minimum (from 0 to $4 \mathrm{~h}$ and from 20 to $24 \mathrm{~h}$ ) or medium (the rest of the day). In Expt 2, a mean digesta sample was obtained for each diet by mixing equal amounts of the representative samples from each measurement. AA were determined by ion-exchange-resin chromatography after hydrolysis of the samples in $5.5 \mathrm{M}$-hydrochloric acid at $120^{\circ}$ for $24 \mathrm{~h}$ and $48 \mathrm{~h}$; the $24 \mathrm{~h}$ hydrolysis period was sufficient for most AA but the longer $48 \mathrm{~h}$ period was necessary for valine and isoleucine (Prugnaud \& Pion, 1976). Before acid-hydrolysis, oxidation with performic acid was carried out to determine sulphur-AA. Diaminopimelic acid content was determined using hydrolysates previously subjected to oxidation according to a method derived from that of Mzik et al. (1978).

\section{Statistical analysis}

The results of each experiment were subjected to a two-way analysis of variance, with variations being ascribed to animals and diets; means were ranked according to the Newman-Keuls' test (Dagnélie, 1970). Also, the two experiments were compared by a three-way analysis of variance, with variations being ascribed to animals, diets and years, using the mean values obtained for each calf with each diet; when the effect of year was significant, the difference for each diet was tested by the Newman-Keuls' test.

Since rapid biochemical methods of analysis are not available to separate the various types of protein in the ileal digesta, we used several methods based on a comparison of the AA composition of digesta with that of dietary, endogenous and microbial proteins. These methods have been previously described in detail by Guilloteau et al. (1983). A first approach consisted of studying the level of some characteristic AA. However, it was more interesting to use methods such as the distance of $\chi^{2}$ and the factorial correspondence analysis which take into account all AA. The distance of $\chi^{2}$ only allows single comparisons to be made between two proteins while the correspondence analysis allows simultaneous comparisons of a large number of proteins.

The distance of $\chi^{2}$ between two proteins $i$ and $j$ was computed as follows:

$$
\chi^{2}=17 \sum_{k=1}^{k=17}(\mathrm{AA} i k-\mathrm{AA} j k)^{2} /((\mathrm{AA} i k+\mathrm{AA} j k) / 2)
$$

where $\mathrm{AA} i k$ and $\mathrm{AA} j k$ are the respective percentages of $\mathrm{AA} k$ in the sum of the assayed AA (diaminopimelic acid excluded) in the proteins $i$ and $j ; k$, which represented the different $A \mathrm{~A}$, varied between 1 and 17. The larger the distance of $\chi^{2}$, the greater the difference between the compared proteins.

The proportions of different proteins which could be the main constituents of digesta protein were assessed by iterative calculation of the theoretical mixture which minimized the distance of $\chi^{2}$ with regard to the composition observed in digesta. This approach has been used by Guilloteau et al. (1980), Darcy et al. (1983) and Kouamé et al. (1984) to study the composition of digesta protein. Likewise, computerized iterative optimization procedures 
to match mixtures of AA profiles in constituents to observed profiles of digesta have been used by Evans et al. (1975) and Cockburn \& Williams (1984).

The basis of factorial correspondence analysis has been described, for example, by Hill (1974). Here, the distance between two proteins $i$ and $j$ was computed as follows:

$$
\begin{aligned}
& d^{2}(i, j)=\sum_{k=1}^{k=p} \frac{1}{\mathrm{AA} \cdot k}\left(\frac{\mathrm{AA} i k-\mathrm{AA} j k}{\mathrm{AA} i .-\mathrm{AA} j .}\right)^{2} \\
& \mathrm{AA} \cdot k=\sum_{i=1}^{i=n} \mathrm{AA} i k, \text { where } n \text { is number of proteins, } \\
& \mathrm{AA} i .=\sum_{k=1}^{k=p} \mathrm{AA} i k, \text { where } k \text { is number of AA, }
\end{aligned}
$$

where $\mathrm{AA} i .=\mathrm{AA} j .=\ldots=\mathrm{AA} n .=100$ since the $\mathrm{AA}$ were expressed as percentages of their sum.

Each protein was considered as a point in a seventeen-dimensional space with seventeen variables corresponding to the assayed AA (diaminopimelic acid excluded). This initial pattern was reduced to the plane obtained with the two axes (called factors) which explained the largest part of total variance $(59-66 \%)$. The smaller the distance between the projections of two proteins, the more similar were the two proteins. It was also possible to represent both protein and AA on the same factorial plane; if the projection of a protein $i$ was closer to that of AA $k$ since in this protein the percentage of this AA was higher than that in the other proteins. This descriptive approach has been used by Guilloteau et al. (1981), Darcy et al. (1983) and Kouamé et al. (1984) to show the composition of digesta protein in comparison with that of dietary, endogenous and bacterial proteins.

\section{Health and growth}

Health condition and appetite of the calves of Expt 1 were generally satisfactory. However, two calves, which received the soya-bean diet during the first period, had to be replaced. Mean (with SE) values for live-weight gain during the weeks of digesta collection were 700 (80), $706(97)$ and 508 (96) g/d when the calves were given the control, fish and soya-bean diets respectively. Animals with re-entrant cannulas showed lower rates of growth than calves with simple cannulas; mean (with SE) values were 494 (65) and $782(57) \mathrm{g} / \mathrm{d}$ respectively.

In Expt 2, the experimental milk-substitutes given to calves were always ingested with no refusals. Mean (with SE) values for live-weight gain during the weeks of digesta collection were $1103(62), 865(107)$ and 960 (78) g/d when the calves received the control, fish and soya-bean diets respectively. These values were higher than those observed in Expt 1 for calves given corresponding diets; this was probably due to a higher level of feed intake for calves of Expt 2 compared with that of animals in Expt 1.

\section{Flow rate}

Results given in Fig. 1 are individual and daily variations in the flow rates of total digesta, $\mathrm{DM}, \mathrm{N}$ and ash with time interval after feeding, of calves receiving diets containing milk, fish and soya-bean protein in Expt 1 . Although these variations were large it was possible to identify a change with time interval after the meal and, especially, two peaks. The first one appeared between 6 and $8 \mathrm{~h}$ after the morning meal irrespective of the diet. The second peak appeared between 4 and $6 \mathrm{~h}$ after the evening meal with the control and soya-bean diets and between 6 and $8 \mathrm{~h}$ with the fish diet. With the fish and, especially, the soya-bean 


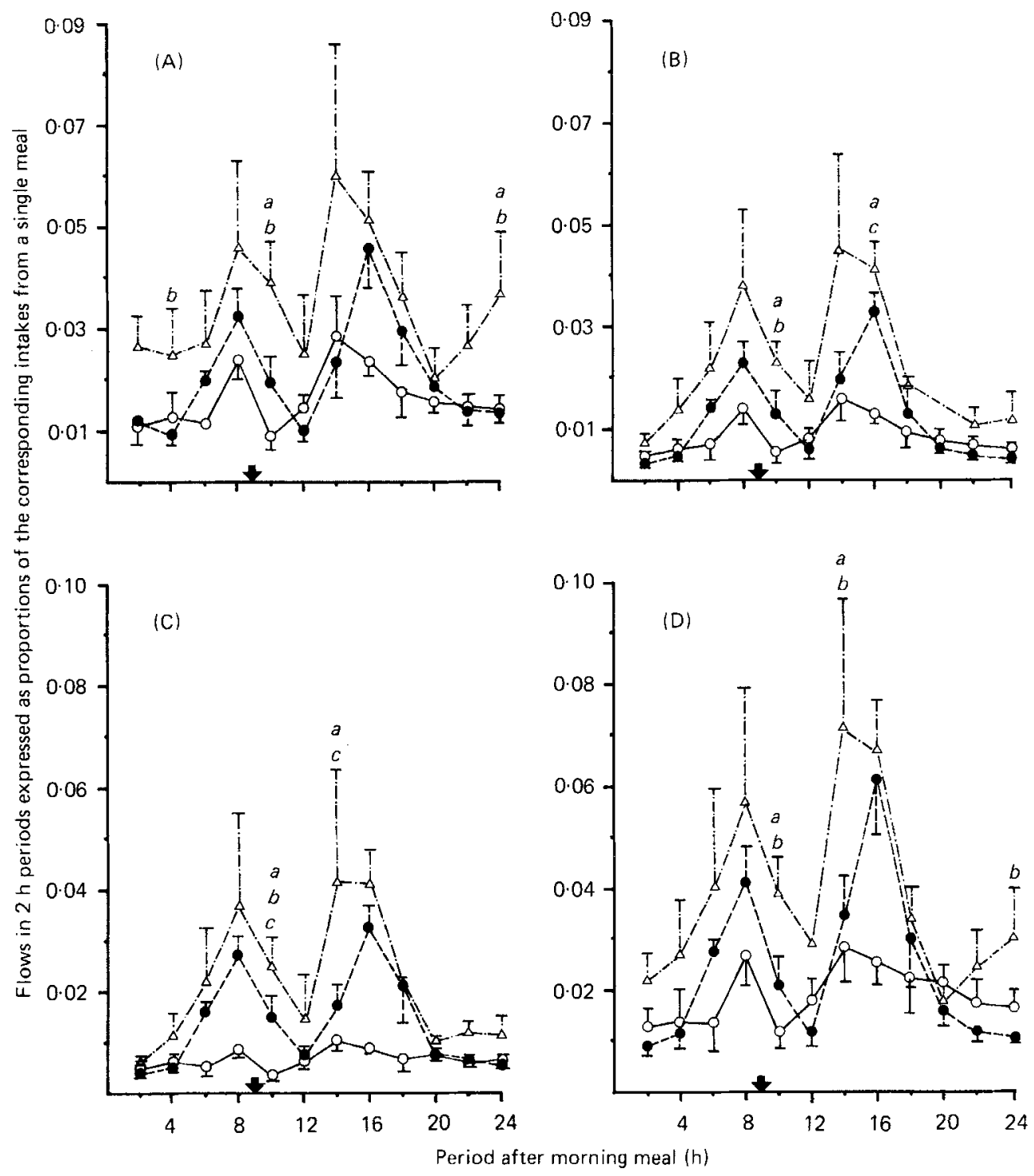

Fig. 1. Expt 1. Relative flows at the terminal ileum at different times after giving preruminant calves diets containing protein from milk (control) $(O)$, fish $(\Theta)$ or soya bean $(\triangle)$. Results are given as mean values, with their standard errors represented by vertical bars, for nine measurements on three calves each equipped with a re-entrant cannula. Values are given for (A) total weight, (B) dry matter, (C) nitrogen and (D) minerals. ( $\downarrow$ ), Evening meal. For details of diets, see p. 572 and Table 1 . Significant differences $(P<0.05)$ were observed at times marked $a, b$ and $c$ between soya-bean and control diets, soya-bean and fish diets, and control and fish diets respectively.

diets the peaks were more marked and the flow rates generally much higher than those with the control diet.

\section{$p H$}

Mean values for $\mathrm{pH}$ of digesta collected at different time intervals after feeding in Expt 1 are given in Fig. 2. These results show two minima which were particularly marked with 


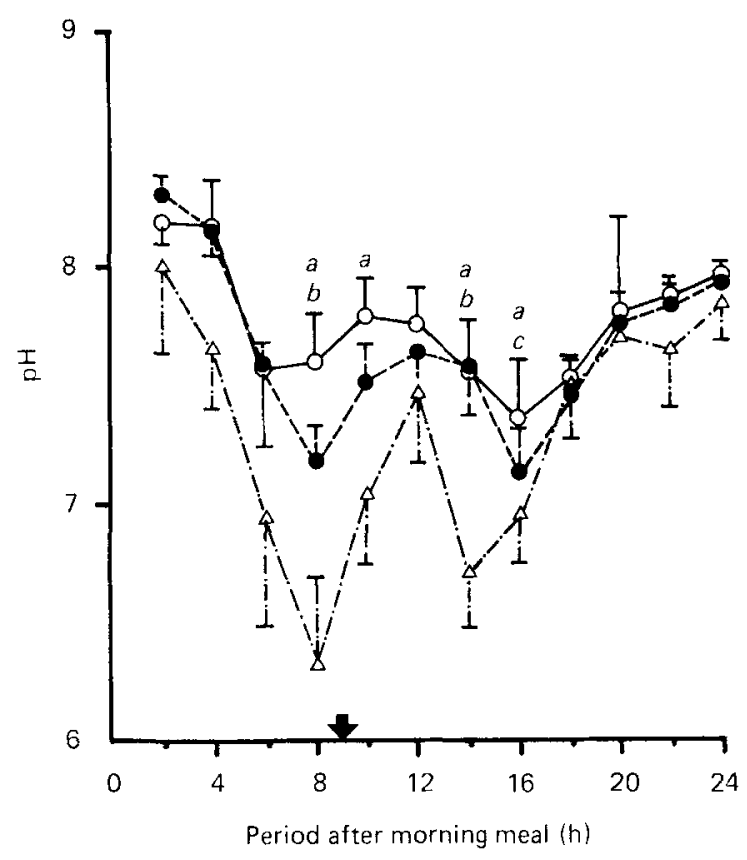

Fig. 2. Expt 1. pH of digesta collected from the terminal ileum at different times after giving preruminant calves diets containing protein from milk (control) $(O)$, fish $(O)$ or soya bean $(\triangle)$. Results are given as mean values, with their standard errors represented by vertical bars, for nine measurements on three calves each equipped with a re-entrant cannula. $(\downarrow)$, Evening meal. For details of diets, see p. 572 and Table 1 . Significant differences $(P<0.05)$ were observed at times marked $a, b$ and $c$ between soya-bean and control diets, soya-bean and fish diets, and control and fish diets respectively.

the soya-bean diet and were observed at about the same time-interval as the maxima in the flow rates. The values observed with the control diet were the highest and the most regular whereas those obtained with the soya-bean diet were the most variable and the lowest.

\section{Ileal apparent digestibility}

Comparisons of apparent digestibilities of DM, organic matter, $\mathrm{N}$, fat, ash and $\mathrm{N}$-free extract up to the terminal ileum are given in Table 3. In Expt 1, the highest values were always obtained with the control diet and the lowest with the soya-bean diet. Digestibilities of all constituents were significantly lower for soya-bean than for either fish or the control diet. Differences between the control and the fish diets were only significant for $\mathrm{N}$.

The apparent digestibility values obtained in Expt 2 were higher than those in Expt 1, especially with the soya-bean diet for which all differences were significant $(P \leqslant 0.05)$. Also, all the differences between values for the two experiments, except values for ash, were significant with the fish diet. In contrast, only the differences observed for $\mathrm{N}$ and $\mathrm{N}$-free extract were significant with the control diet. $\mathbf{N}$ digestibility was significantly higher with the control diet than with the other two diets, but the results were very similar for fish and soya-bean. For all other constituents except fat, digestibility was lower with soya-bean than with either the fish or the control diet. In addition to $\mathrm{N}$ digestibility, those of DM and organic matter were significantly higher with the control diet than with the fish diet.

In Table 4, values of faecal digestibility previously obtained with diets very similar to those used in the present experiments are presented. In Expt 1, ileal digestibilities of all 
Intestinal protein digestion in calves

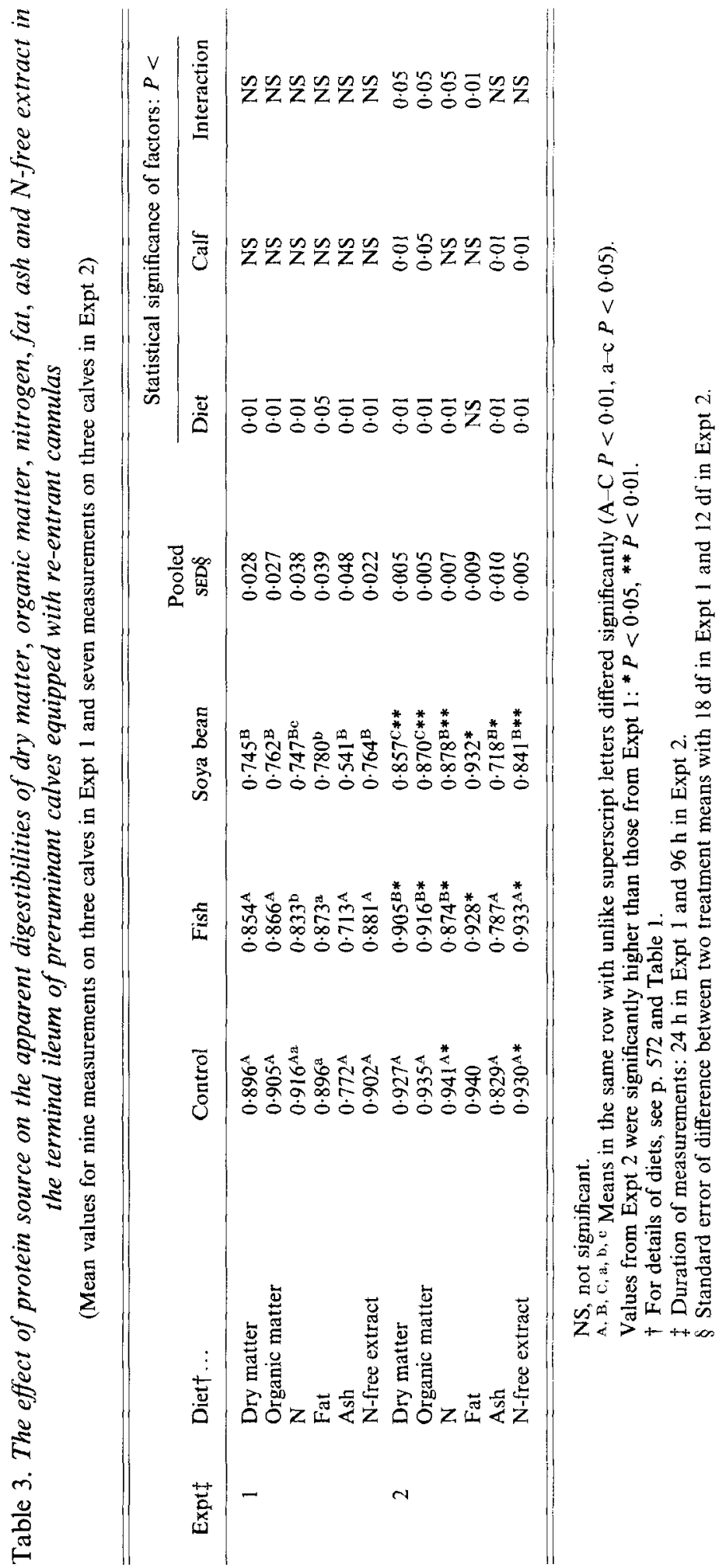




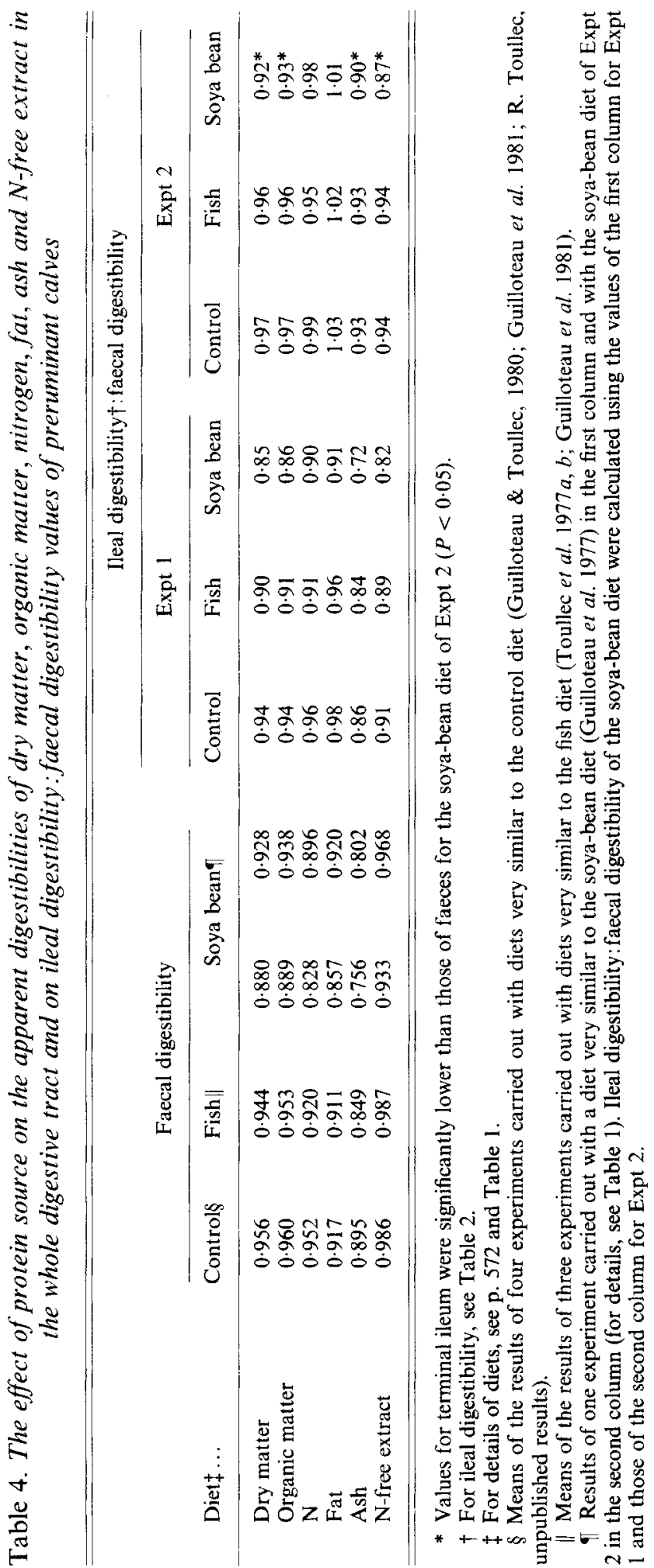


dietary components, especially those of ash and $\mathrm{N}$-free extract, were lower than faecal digestibilities. In Expt 2 the same was true for the control and fish diets, except for the digestibility of fat which was a little higher in the terminal ileum. For the soya-bean diet, ileal digestibilities of fat and $\mathrm{N}$ were much higher than previously obtained faecal values. Therefore, the apparent digestibility of the soya-bean diet used in Expt 2 was measured in four calves by total collection of faeces during two periods of $5 \mathrm{~d}$. The age of the calves was 5 weeks when collection started. The results also showed that digestibility of the soya-bean diet was higher in the whole digestive tract than at the terminal ileum, except for fat.

\section{AA composition of digesta}

Table 5 shows the AA composition of ileal digesta collected at different time intervals from calves fitted with a simple cannula in Expt 1, and during $96 \mathrm{~h}$ from calves equipped with a re-entrant cannula in Expt 2. The AA composition of these digesta was compared with that of dietary, endogenous and gut bacteria proteins by factorial correspondence analysis (Fig. 3). The AA composition of faeces collected from calves receiving diets similar to those used in the present experiments were also introduced in the analysis.

Whatever the diet the percentage of AA-N was lower in the digesta than in the diet (Tables 2 and 5). Digesta protein contained more aspartic acid, threonine and cystine and was generally less rich in isoleucine, leucine, methionine, tyrosine and phenylalanine.

In Expt 1, the AA composition of digesta changed little with the flow rate when the calves were given the control diet (Table 5). Accordingly, distances of $\chi^{2}$ between the compositions observed when the flow rate was minimum (1), medium (2) or maximum (3) were very small (13-15). In the same way, the points representing these three compositions in the plane 1-2 of the correspondence analysis presented in Fig. 3 were very near each other. Moreover, they were closer to the area containing the endogenous proteins than to that containing the faecal and bacterial proteins and to milk protein. Comparisons with the main milk proteins $\left(\alpha \mathrm{s}_{1^{-}}, \alpha \mathrm{s}_{4^{-}}, \beta-, \gamma\right.$-and $\kappa$-caseins, $\alpha$-lactalbumin and $\beta$-lactoglobulin (Jenness, 1974); immunoglobulin (Kickhoffen et al. 1968); serum-albumin (Schultze \& Heremans, 1966)) showed that none of them resembled digesta protein. The least dissimilar was immunoglobulin, but the distance of $\chi^{2}$ between its composition and the mean composition of digesta was high (173).

In contrast to the results with the control diet, values for the other two diets indicated that the aspartic acid, glutamic acid and proline contents of digesta, as well as the glycine content with the fish diet, increased with the flow rate at the expense of most of the other AA (Table 5). Thus, the distance of $\chi^{2}$ between digesta samples at flow rates 1 and 3 reached 138 and 234 for the fish and soya-bean diets respectively; results given in Fig. 3 show that these digesta were 5.5- and 9.2-fold more distant for the fish (F) and soya-bean (S) diets respectively than for the milk (M) diet. Also, the diaminopimelic acid content decreased when the flow rate increased.

When the flow rate was minimum, the AA composition of digesta changed little with the diet (distance of $\chi^{2}=17$ in all the cases). However, differences observed between digesta according to diets increased with the flow rate. For example, the glycine, aspartic acid, methionine and lysine contents of digesta samples at flow rates 2 and 3 were much higher with the fish diet than with the control diet, whilst the aspartic acid and especially the glutamic acid contents were higher with the soya-bean diet. These changes occurred with both diets mainly at the expense of the threonine, serine, valine and tyrosine contents. Thus, compared with the control diet, values for distance of $\chi^{2}$ with the soya-bean diet increased up to 112 and 268 respectively for digesta samples at flow rates 2 and 3 . Likewise, in Fig. 3, the interval was $7 \cdot 1$-fold larger than between M1 and S1. Also, the interval between the 


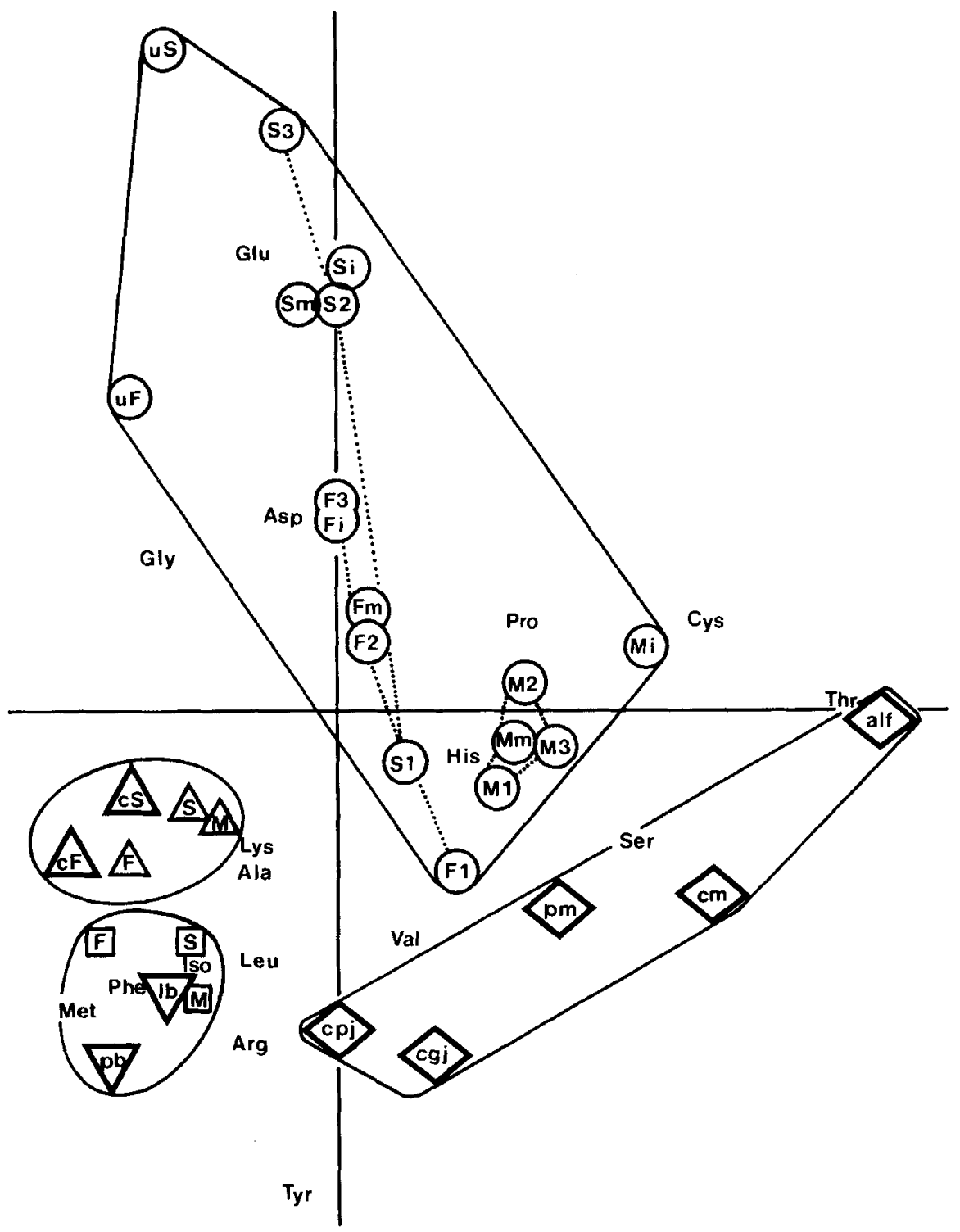

Fig. 3. Comparison of the amino acid (AA) composition ( $\mathrm{g} / \mathrm{kg}$ assayed AA) of protein of ileal digesta (O) and faeces $(\square)$ collected from preruminant calves receiving diets containing different protein sources with that of dietary $(\triangle)$, endogenous $(\diamond)$ and gut bacteria $(\nabla)$ proteins. Each point is the projection of one protein on the principal plane (1-2) of the factorial correspondence analysis. The seventeen AA (Ala, Arg, Asp, etc.) are also projected. M, F, S, control, fish, soya-bean diets respectively; c, protein concentrate; 1, 2, 3, digesta collected in Expt 1 when flow rate was minimum (1), medium (2) and maximum (3); $\mathrm{m}$, i, mean composition of digesta collected in Expt $\mathrm{I}(\mathrm{m})$ and $2(\mathrm{i})$; $\mathrm{u}$, additional undigested protein due to the fish (uF) or soya-bean (uS) diets compared with the control diet in Expt 2; alf, axenic lamb faeces (Combe, 1976); cgj, calf gastric juice (Guilloteau et al. 1983); cm, calf meconium (Grongnet et al. 1981); cpj, calf pancreatic juice (Guilloteau et al. 1983); Ib, sheep faecal bacteria (Mason, 1979); pb, pig faecal bacteria (Mason et al. 1976); pm, pig gastric mucoprotein (Snary \& Allen, 1971). Values of faeces were from experiments carried out with diets similar to those used in the present experiments (Patureau-Mirand et al. 1977). For details of diets, methods and AA composition of ileal digesta, see pp. 572 and 581 and Tables $1,2,5$ and 6. 
Table 6. Amino acid $(A A)$ composition $(\mathrm{g} / \mathrm{kg}$ assayed $A A$ ) of the common mixture of endogenous and bacterial proteins escaping digestion in the small intestine of preruminant calves and of additional undigested protein due to the fish and soya-bean diets as compared with the control diet

(Results are from pooled samples originating from nine measurements on three calves equipped with a simple cannula in Expt 1 and from seven measurements on three calves equipped with a re-entrant cannula in Expt 2)

\begin{tabular}{|c|c|c|c|}
\hline \multirow[b]{2}{*}{$\mathrm{AA}$} & \multirow{2}{*}{$\begin{array}{l}\text { Mixture of ileal } \\
\text { endogenous and } \\
\text { bacterial proteins } \dagger\end{array}$} & \multicolumn{2}{|c|}{ Additional undigested protein* due to: } \\
\hline & & Fish diet & Soya-bean diet \\
\hline Aspartic acid & $102 \cdot 9$ & $138 \cdot 6$ & $138 \cdot 7$ \\
\hline Threonine & $84 \cdot 7$ & $44 \cdot 1$ & $55 \cdot 0$ \\
\hline Serine & $65 \cdot 0$ & $42 \cdot 3$ & $40 \cdot 0$ \\
\hline Glutamic acid & $159 \cdot 2$ & $189 \cdot 3$ & $309 \cdot 8$ \\
\hline Proline & 62.9 & $70 \cdot 9$ & $45 \cdot 7$ \\
\hline Glycine & $51 \cdot 6$ & $129 \cdot 0$ & $65 \cdot 9$ \\
\hline Alanine & $52 \cdot 1$ & $54 \cdot 0$ & $51 \cdot 2$ \\
\hline Valine & $61 \cdot 4$ & $42 \cdot 4$ & $40 \cdot 1$ \\
\hline Cystine & $37 \cdot 2$ & $25 \cdot 6$ & $23 \cdot 4$ \\
\hline Methionine & $13 \cdot 7$ & $22 \cdot 8$ & $8 \cdot 6$ \\
\hline Isoleucine & $38 \cdot 5$ & $38 \cdot 1$ & $33 \cdot 3$ \\
\hline Leucine & $69 \cdot 0$ & $53 \cdot 8$ & $57 \cdot 4$ \\
\hline Tyrosine & $35 \cdot 0$ & $20 \cdot 3$ & 14.8 \\
\hline Phenylalanine & $35 \cdot 0$ & $33 \cdot 3$ & $34 \cdot 3$ \\
\hline Lysine & 65.7 & $33 \cdot 0$ & $33 \cdot 5$ \\
\hline Histidine & $23 \cdot 9$ & $28 \cdot 9$ & $25 \cdot 2$ \\
\hline Arginine & $42 \cdot 1$ & $33 \cdot 5$ & $23 \cdot 3$ \\
\hline
\end{tabular}

* Total amounts of AA recovered at the end of the ileum with the fish or soya-bean diets minus those obtained with the control diet in Expt 2.

$\dagger$ Mean composition of digesta collected with the control diet in Expts 1 and 2 and of digesta collected when flow rate was minimum in Expt 1 with the fish and soya-bean diets; for details, see p. 573 and Table 5 .

position of digesta resulting from the fish and soya-bean diets and that of the endogenous or the bacterial proteins increased with the flow rate. However, the AA composition of digesta remained different from that of the diets and of the protein concentrates (c). This was particularly notable with the soya-bean diet since the distance of $\chi^{2}$ between the soya-bean protein concentrate (cS) and digesta increased from 121 (S1) to 274 (S3). Similarly, in Fig. 3 , the interval was $2 \cdot 5$-fold larger between $\mathrm{cS}$ and S3 than between $\mathrm{CS}$ and S1.

In Expt 2, the AA composition of digesta was similar to the mean composition calculated for Expt 1 (Table 5); this was shown by the small distances of $\chi^{2}(27-50)$ as well as the short intervals in Fig. 3 between Mi and Mm, Fi and Fm, Si and Sm (i, Expt 1; m, Expt 2 ) respectively. The main differences observed in the composition of digesta according to the diet were generally the same as those observed in Expt 1 when the flow rate was maximum or medium. The additional undigested proteins obtained with the fish and soya-bean diets compared with the control diet were richer than the concentrates in aspartic acid, glutamic acid, glycine and cystine (Tables 2 and 6). Accordingly, the distance of $\chi^{2}$ between additional undigested proteins ( $\mathrm{uF}$ and $\mathrm{uS}$ ) and concentrates ( $\mathrm{cF}$ and $\mathrm{cS}$ ) reached 233 (fish) and 361 (soya-bean) respectively. Likewise, in Fig. 3, uF and uS were far from $\mathrm{CF}$ and $\mathrm{CS}$. The AA composition of digesta resulting from the soya-bean diet was also compared with that of different soya-bean proteins (Fig. 4). The protein which was the most dissimilar from uS was the Bowman-Birk trypsin inhibitor (distance of $\chi^{2}=1327$ ). 


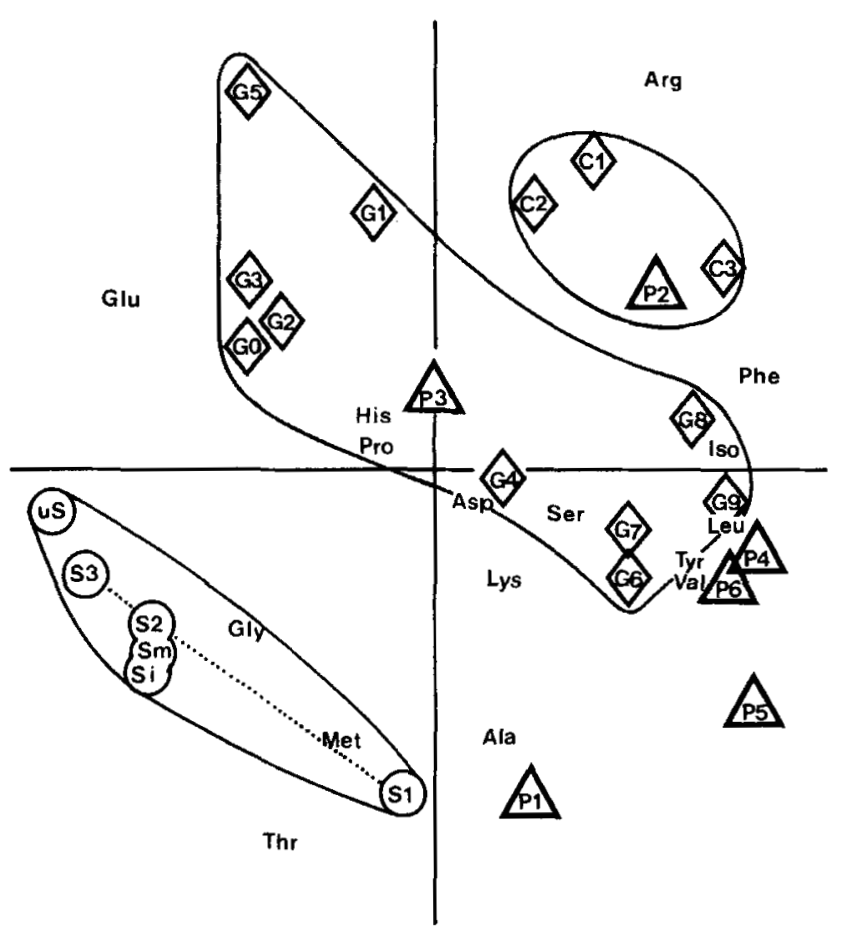

Cys

Fig. 4. Comparison of the amino acid (AA) composition ( $\mathrm{g} / \mathrm{kg}$ assayed AA) of protein of ileal digesta (O) collected from preruminant calves receiving the soya-bean diet with that of dietary proteins $(\triangle$ or $\diamond)$. Each point is the projection of one protein on the principal plane (1-2) of the factorial correspondence analysis. The seventeen AA (Ala, Arg, Asp, etc.) are also projected. S1, S2, S3, digesta collected in Expt 1 when flow rate was minimum (1), medium (2) and maximum (3); Sm, Si, mean composition of digesta collected in Expts $1(\mathrm{~m})$ and 2 (i); uS, additional undigested protein due to the soya-bean diet as compared with the control diet in Expt 2; P1-P6, cytochrome $c$, globulin 7S ( $\beta$-conglycinin), globulin 11S (glycinin), globulin 28S, haemagglutinin, Kunitz trypsin inhibitor respectively (Wolf, 1972); C1, C2, C3, conglycinin sub-units $\alpha, \alpha^{\prime}$ and $\beta$ respectively (Thanh \& Shibasaki, 1977); G0-G9, glycinin sub-units A1, F2 (1), A2, A3, F2 (2), A4, B1, B2, B3 and B4 respectively (Moreira et al. 1979). Due to its particular AA composition (184 g cystine/ $\mathrm{kg} \mathrm{AA}$; Wolf, 1972), Bowman-Birk trypsin inhibitor was very far from the other proteins and was not kept in this analysis. For details of diets, methods and AA composition of ileal digesta, see p. 572 and 581, and Tables 1, 2,5 and 6.

Glycinin, which is the major part of soya-bean protein (Moreira et al. 1979), was the least different one, but the large distance of $\chi^{2}(280)$ showed that this protein as a whole could not constitute an important proportion of uS. Comparison with the glycinin fractions did not reveal any sub-unit which was similar to uS among the ten polypeptides isolated by Moreira et al. (1979). The acid polypeptides A1, A2 and A3 were the least different with distances of $\chi^{2}$ equalling 236, 243 and 255 respectively. The basic polypeptide B4 was the most dissimilar from uS (distance of $\chi^{2}=679$ ).

Finally, the AA composition of faeces changed little with the different diets and was similar to that of gut bacteria (Fig. 3), suggesting that faecal protein was mainly bacterial protein and confirming that the study of protein composition of ileal digesta was more useful for estimating the origin of undigested protein. 


\section{Apparent digestibilities of $A A$ in the small intestine}

The apparent digestibilities of AA up to the terminal ileum are given in Table 7 . They were calculated only for Expt 2 since in Expt 1, AA composition was determined on digesta obtained from calves fitted with a simple cannula. The apparent digestibility of AA-N (diaminopimelic acid excluded) was always slightly higher than that of total N. Digestibilities of cystine and threonine were always lower than that of AA-N whereas digestibilities of methionine, isoleucine, leucine and tyrosine were higher. Cystine was the least digestible with the control diet and arginine with the other two diets. Results for all AA were higher with the control than with the fish and soya-bean diets. Differences between the control and the fish diets were particularly large for histidine, proline, glutamic acid, aspartic acid and valine. Differences between the control and the soya-bean diets were mainly important for glutamic acid, proline, aspartic acid, histidine, glycine and threonine. Differences between the fish and the soya-bean diets only concerned cystine and histidine which were less digestible with the fish diet.

The amounts of AA recovered in the terminal ileum relative to DM intake are presented in Table 8. The undigested amounts were always lower with the control diet than with the fish and soya-bean diets, irrespective of variations in the ingested amounts between the diets. The largest differences were observed for amounts of glycine and glutamic acid which, when compared with the control, were $4 \cdot 4$ - and $4 \cdot 1$-fold higher with the fish and soya-bean diets respectively. The amounts of diaminopimelic acid were 1.6- and 1.7-fold higher with the

Table 7. Expt 2. The effect of protein source on the mean digestibilities of nitrogen and of amino acids $(A A)$ in the terminal ileum of preruminant calves equipped with a re-entrant cannula

(Results are from pooled samples originating from seven measurements on three calves)

\begin{tabular}{|c|c|c|c|c|c|}
\hline \multirow{2}{*}{$\begin{array}{l}\text { Digestibility... } \\
\operatorname{Diet}^{\dagger} \ldots\end{array}$} & \multicolumn{3}{|c|}{ Apparent } & \multicolumn{2}{|c|}{ True* } \\
\hline & Control & Fish & Soya bean & Fish & Soya bean \\
\hline Total $\mathrm{N}$ & 0.941 & 0.873 & $0 \cdot 878$ & 0.929 & 0.933 \\
\hline $\mathrm{N}$ of assayed AA & 0.959 & 0.896 & 0.900 & 0.939 & 0.949 \\
\hline Aspartic acid & 0.955 & 0.868 & 0.882 & 0.908 & 0.913 \\
\hline Threonine & 0.920 & 0.866 & 0.855 & 0.948 & 0.928 \\
\hline Serine & $0-952$ & 0.893 & $0 \cdot 900$ & 0.949 & 0.949 \\
\hline Glutamic acid & 0.965 & 0.860 & 0.834 & 0.915 & 0.874 \\
\hline Proline & 0.965 & 0.862 & 0.887 & 0.925 & 0.945 \\
\hline Glycine & 0.897 & 0.858 & 0.830 & 0.890 & 0.884 \\
\hline Alanine & $0-934$ & 0.908 & 0.873 & 0.947 & 0.921 \\
\hline Valine & 0.963 & 0.892 & 0.901 & 0.947 & 0.948 \\
\hline Cystine & 0.820 & 0.775 & 0.825 & 0.894 & 0.912 \\
\hline Methionine $\ddagger$ & 0.984 & 0.925 & 0.939 & 0.943 & 0.963 \\
\hline Isoleucine & 0.974 & 0.916 & 0.930 & 0.950 & 0.957 \\
\hline Leucine & 0.975 & 0.923 & 0.925 & 0.956 & 0.952 \\
\hline Tyrosine & 0.979 & 0.921 & 0.944 & 0.959 & 0.973 \\
\hline Phenylalanine & 0.975 & 0.907 & 0.921 & 0.944 & 0.947 \\
\hline Lysine & 0.956 & 0.933 & 0.927 & 0.976 & 0.969 \\
\hline Histidine & 0.966 & 0.851 & 0.895 & 0.908 & 0.933 \\
\hline Arginine & 0.967 & 0.940 & 0.957 & 0.964 & 0.975 \\
\hline
\end{tabular}

* Values calculated assuming that the true digestibility of milk AA was complete and that the amounts of AA per $\mathrm{kg}$ dry matter intake flowing from the terminal ileum with the control diet represented the endogenous contributions with the other two diets (see Table 8 ).

$\dagger$ For details of diets and methods, see pp. 572-574, and Table 1.

+ Values of dietary methionine and lysine calculated assuming that synthetic AA were fully absorbed. 
Table 8. Expt 2. The effect of protein source on the amounts $(\mathrm{g} / \mathrm{kg}$ dry matter intake) of amino acids $(A A)$ present in the diet (In) and flowing from the terminal ileum (II) of preruminant calves equipped with a re-entrant cannula

(Results are from pooled samples originating from seven measurements on three calves)

\begin{tabular}{|c|c|c|c|c|c|c|c|c|c|}
\hline \multirow[b]{2}{*}{$\mathrm{AA}$} & & \multicolumn{3}{|c|}{ Diet $^{*}$} & \multirow[b]{2}{*}{ AA } & & \multicolumn{3}{|c|}{ Diet* } \\
\hline & & Control & Fish & $\begin{array}{l}\text { Soya } \\
\text { bean }\end{array}$ & & & Control & Fish & $\begin{array}{l}\text { Soya } \\
\text { bean }\end{array}$ \\
\hline \multirow[t]{2}{*}{ Aspartic acid } & In & $18 \cdot 09$ & $20 \cdot 21$ & $26 \cdot 56$ & Methionine $\dagger$ & In & $6 \cdot 42$ & $5 \cdot 46$ & $4 \cdot 05$ \\
\hline & Il & 0.82 & 2.68 & $3 \cdot 14$ & & Il & $0 \cdot 10$ & 0.41 & 0.25 \\
\hline \multirow[t]{2}{*}{ Threonine } & In & $11 \cdot 63$ & 11.41 & $12 \cdot 78$ & Isoleucine & In & $13 \cdot 16$ & $10 \cdot 17$ & $12 \cdot 90$ \\
\hline & Il & 0.94 & $1 \cdot 53$ & 1.86 & & Il & 0.34 & 0.85 & 0.90 \\
\hline \multirow[t]{2}{*}{ Serine } & In & $13 \cdot 39$ & $11 \cdot 28$ & $13 \cdot 16$ & Leucine & In & $22 \cdot 44$ & $16 \cdot 61$ & $20 \cdot 11$ \\
\hline & II & 0.64 & $1 \cdot 21$ & $1 \cdot 31$ & & Il & 0.55 & $1 \cdot 28$ & $1 \cdot 52$ \\
\hline \multirow[t]{2}{*}{ Glutamic acid } & In & 46.53 & $30 \cdot 01$ & $41 \cdot 11$ & Tyrosine & In & $12 \cdot 57$ & $6 \cdot 82$ & $9 \cdot 11$ \\
\hline & Il & 1.65 & $4 \cdot 19$ & 6.84 & & $\mathrm{Il}$ & 0.26 & 0.54 & 0.51 \\
\hline \multirow[t]{2}{*}{ Proline } & In & $22 \cdot 56$ & $12 \cdot 65$ & $13 \cdot 79$ & Phenylalanine & In & $11 \cdot 04$ & $7 \cdot 81$ & $10 \cdot 75$ \\
\hline & Il & 0.80 & 1.75 & 1.56 & & I! & 0.28 & 0.72 & 0.85 \\
\hline \multirow{2}{*}{ Glycine } & In & 4.93 & $15 \cdot 75$ & $9 \cdot 49$ & Lysine $\dagger$ & In & $17 \cdot 62$ & $18 \cdot 10$ & $18 \cdot 34$ \\
\hline & Il & 0.51 & $2 \cdot 24$ & 1.61 & & Il & 0.77 & $1 \cdot 21$ & $1 \cdot 33$ \\
\hline \multirow[t]{2}{*}{ Alanine } & In & $7 \cdot 87$ & $13 \cdot 52$ & $10 \cdot 88$ & Histidine & In & $7 \cdot 05$ & $4 \cdot 22$ & $6 \cdot 32$ \\
\hline & Il & 0.52 & $1 \cdot 24$ & $1 \cdot 38$ & & Il & 0.24 & 0.63 & 0.66 \\
\hline \multirow[t]{2}{*}{ Valine } & In & $15 \cdot 98$ & 10.79 & $12 \cdot 78$ & Arginine & In & $8 \cdot 81$ & $12 \cdot 40$ & $15 \cdot 69$ \\
\hline & Il & 0.60 & $1 \cdot 17$ & $1 \cdot 27$ & & Il & 0.29 & 0.74 & 0.68 \\
\hline \multirow[t]{2}{*}{ Cystine } & In & $2 \cdot 11$ & $3 \cdot 22$ & $4 \cdot 43$ & Diaminopimelic & In & - & - & - \\
\hline & $\mathrm{Il}$ & $0 \cdot 38$ & 0.72 & 0.77 & acid & Il & 0.012 & 0.019 & 0.020 \\
\hline
\end{tabular}

* For details of diets and methods, see pp. 572-574, and Table 1.

$\uparrow$ Supplements excluded.

fish and soya-bean diets respectively, suggesting that the amount of microbial protein had increased but this change was less than the total amounts of AA-N which were 2.5- and $2 \cdot 7$-fold higher, respectively.

\section{DISCUSSION}

At the end of the ileum the meal caused an increase in the flow rate of total digesta, DM, $\mathrm{N}$ and minerals observed between 2 and $4 \mathrm{~h}$ after feeding (Fig. 1). However, compared with the fish and soya-bean diets, this influence of the meal was much less marked with the control diet because of its higher digestibility. In the same way, Mylrea (1966a, $b$ ), Van Weerden et al. (1977) and Guilloteau \& Toullec (1980) reported that the meal had little effect on the flow rate at the end of the ileum of calves given diets in which the protein was supplied by skim-milk. From our results it was difficult to estimate accurately the transit time of dietary components in the small intestine since markers were not used and because of the presence of large proportions of endogenous components in ileal digesta. Flow rates were higher with the fish and the soya-bean diets than with the control diet. The increase observed with the soya-bean diet was of the same order as that reported by Sissons \& Smith (1976) and Sissons et al. (1979) when casein was replaced by ethanol-treated soya-bean meal.

In Expt 1, the apparent digestibility of the control diet was very close to that obtained in identical conditions in another experiment with a diet of very similar composition (Guilloteau \& Toullec, 1980). The ileal digestibilities of $\mathrm{N}$ for the control, fish and soya-bean diets could be ranked in the same order as those observed in the faeces for corresponding diets (Table 4). Nevertheless, values of Expt 2 were systematically higher than those of Expt 
1. The variability of results was lower in Expt 2, indicating more satisfactory physiological conditions in spite of the lack of mineral absorption for many days in the large intestine. This suggests that the periods of collection must be long enough or that the animals have to be adapted to the complete deprivation of ileal digesta entering the large intestine for a few days before digesta collection, or both. Under our experimental conditions, opening of the cannulas could have lead to an increase in the flow rate during the following $24 \mathrm{~h}$. This would, however, have been in contradiction with most results obtained in the ruminant, indicating a decreased flow rate during the first 24 or $48 \mathrm{~h}$ of collection from the duodenum and the ileum (MacRae, 1974; Ehouinsou, 1976).

The differences between the two experiments were particularly marked with the soya-bean diet. For $\mathrm{N}$ the ratio, digestibility in Expt 2:digestibility in Expt 1 was $1 \cdot 18$, compared with 1.03 and 1.05 for the control and fish diets respectively. It is possible that the method of preparation of the soya-bean-protein concentrate had been improved during the period between the two experiments. For example, conditions of temperature and ethanol concentration during treatment of soya-bean meal have been shown to be critical for denaturation of soya-bean antigens (Sissons et al. 1982).

To estimate the amounts of nutrients apparently absorbed in the small intestine and in the large intestine respectively, it appeared to be more appropriate to use the results of Expt 2 since the measurements were made over a longer period and the values were higher (Table 3). With the three diets, $\mathrm{N}$ absorption seemed to be almost complete in the distal ileum since the amounts of $\mathrm{N}$ which disappeared in the large intestine represented only $1-5 \%$ of the amounts which disappeared from the whole digestive tract. Use of faecal digestibility would just slightly underestimate the differences between proteins at least when their digestibilities are high. A small percentage of the $\mathrm{N}$-free extract (about $6 \%$ of the total apparently digested amounts) disappeared in the large intestine with the control and fish diets; this percentage was much larger (about $13 \%$ ) with the soya-bean diet. It is likely that after calves received the fish and control diets the $\mathrm{N}$-free extract was mainly of endogenous origin since lactose digestion is almost complete in the small intestine (Besle et al. 1980). Although the carbohydrates of the soya-bean-protein concentrate were not liable to be attacked by the enzymes of the animal, a substantial part (about $60 \%$ of the total quantities disappearing in the whole digestive tract) seemed to be digested in the small intestine. The lower $\mathrm{pH}$ value of the ileal digesta observed with the soya-bean diet in Expt 1 was probably due to the transformation of these carbohydrates into volatile fatty acids by intestinal bacteria. A decrease in the $\mathrm{pH}$ of the ileal digesta was also mentioned by Assan \& Thivend (1976) in calves given a large amount of starch. Disappearance of minerals from the small intestine showed little variation with diet, but a large percentage $(7-10 \%$ of the total apparently digested amounts) was absorbed in the large intestine. In agreement with the results of Van Hellemond \& Van Weerden (1973), digestion of fat was apparently complete at the end of the ileum; the values for ileal:faecal digestibility being always a little greater than 1 , it appeared that the microbial development resulted in a net synthesis of fat in the hind gut.

In Expt 1, the AA composition of digesta resulting from the fish and soya-bean diets depended on flow rate. The validity of this result is questionable since the digesta samples used for AA analysis were collected from calves fitted with a simple cannula while flow rate was measured in calves fitted with a re-entrant cannula. However, the mean AA composition of Expt 2 was very similar to the mean value of Expt 1 (Fig. 3), especially with the soya-bean diet for which the variations according to flow rate were the largest. Thus, it appears that the digesta samples obtained from calves fitted with a simple cannula were satisfactorily representative as far as AA composition was concerned.

When calves were given the control diet the AA composition of digesta was very similar to that obtained in milk-fed calves in a previous experiment (Guilloteau et al. 1980). In all 
cases, the AA composition of digesta was very different from that of the whole diet or of any milk protein. Also, it was very different from that of bacterial protein but resembled more that of endogenous proteins (Fig. 3). The diaminopimelic acid content was much lower in the digesta $(1 \cdot 2-1.8 \mathrm{~g} / \mathrm{kg} \mathrm{AA})$ than in the faeces of milk-fed calves $(6.3 \mathrm{~g} / \mathrm{kg} \mathrm{AA}$ according to Guilloteau et al. 1980). This finding confirms that the proportion of bacterial protein was low in the ileal digesta. Digesta were also much richer than the faeces in hexosamines (12.9-15.5 g/16 g N, instead of $6.1 \mathrm{~g} / 16 \mathrm{~g} \mathrm{~N}$, according to Combe et al. 1980) which suggests a much higher level of mucoprotein in the digesta. Further support for this conclusion is provided by the fact that the position for the digesta of the milk-fed calf in Fig. 3 is close to that for gastric mucoprotein in the pig. The AA which appeared to be the most typical of undigested endogenous protein were threonine, cystine and serine whereas for bacterial protein they were methionine, phenylalanine and isoleucine; the former group of AA was also much more distinctive of protein of the ileal digesta from milk-fed calves than the latter group. It appears that protein of digesta resulting from the control diet was mainly endogenous protein and, to a lesser extent, microbial protein. The same was true of digesta collected in Expt 1 when the flow rate was minimum with the other two diets.

Thus, it appears that a common mixture of endogenous and bacterial proteins may exist at the end of the ileum irrespective of the nature of dietary protein. The AA composition of this mixture was assessed by calculating the mean composition of the digesta obtained with the control diet in both experiments and with the fish and soya-bean diets when the flow rate was minimum in Expt 1 (Table 6). Assuming that the undigested endogenous protein had the mean composition of axenic lamb faeces (Combe, 1976) and of calf meconium (Grongnet et al. 1981), and that the protein of the gut bacteria had the mean composition of pig (Mason et al. 1976) and sheep (Mason, 1979) faecal bacteria, it was possible to determine by iterative calculation the theoretical mixture of endogenous and bacterial proteins, the composition of which was the most approximate to that actually observed (Table 6). The proportions were 0.65 and 0.35 respectively with a $\chi^{2}$ of 24 between the theoretical and observed compositions. This confirms the very high true digestibility of milk protein (Roy et al. 1970; Guilloteau et al. 1980).

In Expt 1, the AA composition of digesta resulting from the fish and soya-bean diets became more different from that of endogenous and bacterial proteins when the flow rate increased (Fig. 3); the AA which appeared the most characteristic of that finding were glutamic acid with the soya-bean diet and glycine and aspartic acid with the fish diet. Therefore, the proportions of endogenous and bacterial proteins seemed to decrease. This assumption was strengthened by the reduction in the hexosamine content which decreased from $10 \cdot 1 \mathrm{~g} / 16 \mathrm{~g} \mathrm{~N}$ when the flow rate was minimum to $6.6 \mathrm{~g} / 16 \mathrm{~g} \mathrm{~N}$ when it was maximum with the soya-bean diet (Combe et al. 1980). The diaminopimelic acid content also decreased (Table 5). Accordingly, the proportion of dietary protein appeared to increase with the flow rate. However, the AA composition of the digesta remained different from that of the diets and of the concentrates (Fig. 3). In Expt 2 the same was true of the AA composition of the additional undigested proteins obtained with the fish and soya-bean diets compared with the control diet.

Therefore, there were particular fractions of fish and soya-bean proteins which escaped digestion in the small intestine. Since the fish concentrate was made of different species, the AA composition of its fractions was not well known. However, the high glycine content of the additional undigested protein indicates that a fraction of fish solubles, which are particularly rich in this AA (Soares et al. 1970; Miller, 1973), was not totally digested in the small intestine. The composition of soya-bean proteins has been more extensively investigated (Wolf, 1972; Thanh \& Shibasaki, 1977; Moreira et al. 1979). None of these 
proteins seemed to resist at least partial digestion in the small intestine since their composition was always very different from that of the additional undigested protein (Fig. 4). However, among the ten polypeptides isolated from glycinin by Moreira et al. (1979), subunits A1, A2 and A3 had a very high glutamic acid content (270-280 g/ $\mathrm{kg} \mathrm{AA})$ and their glutamic acid:aspartic acid value was the most similar to that observed in the additional undigested protein $(2 \cdot 56,2.27$ and 2.23 respectively, instead of $2 \cdot 23)$. These polypeptides probably constituted an important part of the soya-bean fractions not fully digested in the small intestine. However, the levels of some AA in these subunits were very different from those observed in the additional undigested protein; for example, the arginine contents were 69,87 and $77 \mathrm{~g} / \mathrm{kg}$ AA respectively, instead of $23 \mathrm{~g} / \mathrm{kg}$ AA. Presumably particular fractions rather than the intact polypeptides $\mathrm{A} 1, \mathrm{~A} 2$ and $\mathrm{A} 3$ resisted proteolysis. The elements of the primary structure given by Moreira et al. (1979) are not sufficient to examine this hypothesis in more detail since they only involve the twenty-five AA of that end of the polypeptide chain with a terminal amino group.

The apparent digestibility of all AA was much higher with the control diet than with the fish and soya-bean diets (Table 7). In agreement with our previous observations on milk and methanol-grown-bacteria proteins (Guilloteau et al. 1980), the apparent digestibility of threonine and especially of cystine was much lower while that of methionine was higher than the mean value. The true digestibility of AA provided by the fish and soya-bean diets was calculated assuming that true digestibility of milk AA was complete and that there was no increase in the endogenous supplies of $\mathrm{AA}$ and in the alteration resulting from microbial development (Table 7). The differences between the two diets were small and, among the essential AA, cystine was always the least digestible, followed by histidine (fish diet) or by threonine (soya-bean diet).

It may be concluded that it is preferable to start the total deprivation of ileal digesta a few days before the beginning of measurements and that the collection periods should be longer than $24 \mathrm{~h}$. Digestion of milk protein is almost complete in the small intestine of the preruminant calf since proteins recovered in ileal digesta are mainly endogenous proteins from which a part is probably transformed into bacterial protein, especially in the distal part of the small intestine. When casein is replaced by a fish-protein or soya-bean-protein concentrate the undigested amounts of AA increase in ileal digesta, but the proportions of endogenous proteins and of bacterial proteins decrease. The true digestibilities of fish and soya-bean proteins are therefore lower than that of milk protein. Particular fractions of the dietary proteins rich in glycine (fish solubles) and in glutamic acid (glycinin of soya-bean) appear to resist digestion in the small intestine.

The authors are grateful to Dr J. W. Sissons for helpful discussion. The technical assistance of Mrs Marguerite Beaufils, Mrs Odile Bernard, Mr S. Boussion, Mrs Mireille Connan, Mr J. Lareynie and Mrs Marie-Claude Valluy is gratefully acknowledged. Thanks are due to Mrs Jeanine Quillet for collecting the bibliographical information and to Mrs Annick Bouroche for translating the French manuscript into English.

\section{REFERENCES}

Ash, R. W. (1962). Animal Production 4, 309-312.

Assan, E. B. \& Thivend, P. (1976). Proceedings of the Nutrition Society 35, 104A-105A.

Barratt, M. E. J. \& Porter, P. (1979). Journal of Immunology 2, 676-680.

Besle, J. M., Lassalas, B. \& Thivend, P. (1980). Reproduction, Nutrition, Développement 20, 1401-1414.

Cockburn, J. E. \& Williams, A. P. (1984). British Journal of Nutrition 51, 111-132.

Colvin, B. M., Lowe, R. A. \& Ramsey, H. A. (1969). Journal of Dairy Science 52, 687-688.

Combe, E. (1976). Comptes Rendus des Séances de la Société de Biologie 170, 787-793. 
Combe, E., Patureau-Mirand, P., Bayle, G. \& Pion, R. (1980). Reproduction, Nutrition, Développement 20 , $1707-1715$.

Dagnélie, P. (1970). Théorie et Méthodes Statistiques, vol. 2, p. 153. Gembloux: Duculot.

Darcy, B., Laplace, J. P. \& Duée, P. H. (1983). Annales de Zootechnie 32, 315-340.

Ehouinsou, M. A. (1976). Etude de la digestion du lactose chez le mouton. Thèse de Docteur-Ingénieur, University of Clermont-Ferrand.

Evans, R. A., Axford, R. F. E. \& Offer, N. W. (1975). Proceedings of the Nutrition Society 34, 65 A.

Garnot, P., Toullec, R., Thapon, J. L., Martin, P., Minh-Thu, H., Mathieu, C. M. \& Ribadeau Dumas, B. (1977). Journal of Dairy Research 44, 9-23.

Gaudreau, J. M. \& Brisson, G. J. (1980). Journal of Dairy Science 63, 426-440.

Gorrill, A. D. L., Thomas, J. W., Stewart, W. E. \& Morrill, J. L. (1967). Journal of Nutrition 92, 86-92.

Grongnet, J. F., Patureau-Mirand, P., Toullec, R. \& Prugnaud, J. (1981). Annales de Zootechnie 30, $443-464$.

Guilloteau, P., Paruelle, J. L., Toullec, R. \& Mathieu, C. M. (1975). Annales de Zootechnie 24, 243-253.

Guilloteau, P., Patureau-Mirand, P., Toullec, R. \& Prugnaud, J. (1980). Reproduction, Nutrition, Développement 20, 615-629.

Guilloteau, P., Sauvant, D. \& Patureau-Mirand, P. (1983). Annals of Nutrition and Metabolism 27, 457-469.

Guilloteau, P. \& Toullec, R. (1980). Reproduction, Nutrition, Développement 20, 601-613.

Guilloteau, P., Toullec, R., Culioli, J. \& Le Douaron, D. (1977). Annales de Zootechnie 26, 15-28.

Guilloteau, P., Toullec, R., Patureau-Mirand, P. \& Prugnaud, J. (1981). Reproduction, Nutrition, Développement 21, 885-899.

Guilloteau, P., Toullec, R., Sauvant, D. \& Paruelle, J. L. (1979). Annales de Zootechnie 28, 1-17.

Hill, M. O. (1974). Applied Statistics 23, 340-354.

Jenkins, K. J. \& Emmons, D. B. (1982). Nutrition Reports International 26, 635-643.

Jenness, R. (1974). In Lactation. A Comprehensive Treatise, vol. 3. Nutrition and Biochemistry of Milk Maintenance, p. 3 [B. L. Larson and V. R. Smith, editors]. New York: Academic Press.

Kickhoffen, B., Hammer, D. K. \& Scheel, D. (1968). Hoppe-Seyler's Zeitschrift für Physiologische Chemie 349, 1755-1773.

Kilshaw, P. J. \& Sissons, J. W. (1979). Research in Veterinary Science 27, 366-371.

Kouamé, K. G., Patureau-Mirand, P., Troccon, J. L., Prugnaud, J., Journet, M. \& Pion, R. (1984). Annales de Zootechnie 33, 445-466.

MacRae, J. C. (1974). Proceedings of the Nutrition Society 33, 147.

Mason, V. C. (1979). Zeitschrift für Tierphysiologie, Tierernährung und Futtermittelkunde 41, 131-139.

Mason, V. C., Just, A. \& Bech-Andersen, S. (1976). Zeitschrift für Tierphysiologie, Tierernährung und Futtermittelkunde 36, 310-324.

Miller, D. (1973). Feedstuffs 45, 29.

Moreira, M. A., Hermodson, M. A., Larkins, B. A. \& Nielsen, N. C. (1979). Journal of Biological Chemistry 254, 9921-9926.

Mylrea, P. J. (1966a). Research in Veterinary Science 7, 333-341.

Mylrea, P. J. (1966 b). Research in Veterinary Science 7, 394-406.

Mzik, J., Hogan, J. P., Lindsay, J. R. \& Davis, P. (1978). Journal of Chromatography 152, 269-271.

Paruelle, J. L., Toullec, R., Patureau-Mirand, P. \& Mathieu, C. M. (1974). Annales de Zootechnie 23, 519-535.

Patureau-Mirand, P., Toullec, R., Guilloteau, P. \& Pion, R. (1977). Annales de Biologie Animale Biochimie Biophysique 17, 71-83.

Prugnaud, J. \& Pion, R. (1976). Journée de Biochimie, p. 4. Paris: Beckman Instruments, France.

Roy, J. H. B., Stobo, I. J. F. \& Gaston, H. J. (1970). British Journal of Nutrition 24, 441-457.

Roy, J. H. B., Stobo, I. J. F., Shotton, S. M., Ganderton, P. \& Gillies, C. M. (1977). British Journal of Nutrition 38, $167-187$

Schultze, H. E. \& Heremans, J. F. (1966). Molecular Biology of Human Proteins, with Special Reference to Plasma Proteins, vol. 1, p. 182. Amsterdam: Elsevier Publishing Company.

Seegraber, F. J. \& Morrill, L. L. (1982). Journal of Dairy Science 65, 1962-1970.

Sissons, J. W. \& Smith, R. H. (1976). British Journal of Nutrition 36, 421-438.

Sissons, J. W., Smith, R. H. \& Hewitt, D. (1979). British Journal of Nutrition 42, 477-485.

Sissons, J. W., Smith, R. H., Hewitt, D. \& Nyrup, A. (1982). British Journal of Nutrition 47, $311-318$.

Smith, R. H. \& Sissons, J. W. (1975). British Journal of Nutrition 33, 329-349.

Snary, D. \& Allen, A. (1971). Biochemical Journal 123, 845-853.

Soares, J. H., Miller, D. \& Ambrose, M. E. (1970). Feedstuffs 42, 65.

Ternouth, J. H., Roy, J. H. B., Thompson, S. Y., Toothill, J., Gillies, C. M. \& Edwards-Webb, J. D. (1975). British Journal of Nutrition 33, 181-196.

Thanh, V. H. \& Shibasaki, K. (1977). Biochimica et Biophysica Acta 490, 370-384.

Toullec, R., Coroller, J. Y. \& Patureau-Mirand, P. (1977a). Annales de Zootechnie 26, 523-532.

Toullec, R., Guilloteau, P. \& Coroller, J. Y. (1979a). Annales de Biologie Animale Biochimie Biophysique 19, $729-732$. 
Toullec, R., Paruelle, J. L., Coroller, J. Y. \& Le Treut, J. H. (1977b). Annales de Zootechnie 26, $29-43$.

Toullec, R., Thivend, P. \& Mathieu, C. M. (1971). Annales de Biologie Animale Biochimie Biophysique 11, $435-453$. Toullec, R., Thivend, P. \& Theriez, M. (1979b). World Animal Review 33, 32-42.

Van Hellemond, K. K. \& Van Weerden, E. J. (1973). Proceedings of the Nutrition Society 32, $231-235$.

Van Weerden, E. J., Huisman, J. \& Van Hellemond, K. K. (1977). Landbouwkundig Tijdschrift 89, 217-224.

Williams, V. J., Roy, J. H. B. \& Gillies, C. M. (1976). British Journal of Nutrition 36, 317-335.

Wolf, W. J. (1972). In Soyabeans: Chemistry and Technology, pp. 93-143 [A. K. Smith and S. J. Circle, editors]. Westport: Avi Publishing Company.

Zebrowska, T., Buraczewska, L. \& Buraczewski, S. (1978). Roczniki Nauk Rolniczych Seria B Zootechnia 99, 87-97. 